\title{
AEROMAGNETIC MAP OF THE BERNARDSVILLE AND PART OF THE BOUND BROOK QUADRANGLES, MIDLLESEX SOMERSET, AND MORRIS COUNTIES, NEW JERSEY
} By

John R. Henderson, Natalie Tyson, Sybil Gilchrist and others

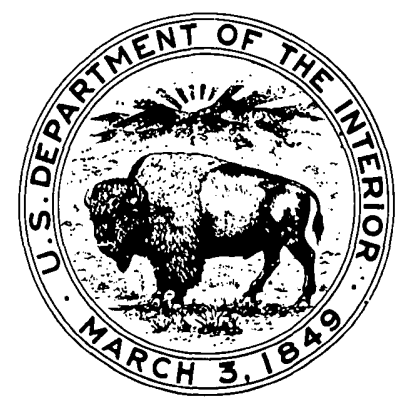

